\title{
Reduction of soil water content fluctuations and soil temperature variations under retrievable drip irrigation
}

\author{
Khumbulani DHAVU ${ }^{1 *}$, Hiroshi YASUDA ${ }^{2}$, Aidan SENZANJE ${ }^{3}$ and Hisao ANYOJI ${ }^{2}$ \\ ${ }^{1}$ Agricultural Research Council, Insititute for Agricultural Engineering, 141 Cresswell Road, Silverton, 0127, \\ Pretoria, South Africa. \\ ${ }^{2}$ Arid Land Research Center, Tottori University, 1390 Hamasaka, Tottori, 680-0001, Japan. \\ ${ }^{3}$ Bioresources Engineering, School of Engineering, University of KwaZulu-Natal, Pietermaritzburg, Private Bag X01, \\ Scottsville, 3209, South Africa.
}

Received 30 September, 2013; Accepted 7 April, 2014

\begin{abstract}
Wide soil water content and temperature variations affect crop yields for reasons ranging from rate of seed germination, seed development, to plant growth. This study aimed at evaluating the extent to which drip irrigation can reduce soil water content and temperature variations. An experiment was carried out in a $154 \mathrm{~m}^{2}$ glasshouse with Tottori dune sand of Japan. Two irrigation levels of 60 and $100 \%$ of evapotranspiration, and two dune sand covers of 2 and $5 \mathrm{~cm}$ on the drip lines were used. Soil water content and temperature variations were significantly $(P<0.001)$ reduced under the $5 \mathrm{~cm}$ dune sand cover but insignificantly reduced under the $2 \mathrm{~cm}$ dune sand cover. Minimum soil temperature was increased, and maximum soil temperature was decreased under the $5 \mathrm{~cm}$ dune sand cover. Irrigation level of $100 \%$ of evapotranspiration under $5 \mathrm{~cm}$ dune sand cover resulted in $20 \%$ dry matter yield increase of sorghum. Irrigation level of $60 \%$ of evapotranspiration under $5 \mathrm{~cm}$ dune sand cover resulted in no significant dry matter yield increase of sorghum. From this study, we conclude that the practical minimum depth of dune sand cover on the drip lines can be $5 \mathrm{~cm}$.
\end{abstract}

Key word: Irrigation level, sand dune soil, soil temperature, surface drip irrigation, water content.

\section{INTRODUCTION}

Water resources in the world are finite. The population in the world benefits from the efficient use of the water resources. Irrigation is the largest consumer of fresh water on earth (Shiklomanov, 1998), using 60\% of all freshwater withdrawals. To reduce the severity of water scarcity, water management must be improved.
Agriculture offers the greatest potential for solving the problem of global water scarcity (Longo and Spears, 2003) through efficient use of water.

Surface drip irrigation has been used for agricultural production for more than three decades, has higher water use efficiency than other irrigation methods and more is 
efficient in keeping stable soil water content and soil temperature variations than other irrigation methods (Camp, 1998). Surface drip irrigation can keep sufficient soil water content and high soil temperature for seed germination and seedling development (Wang et al., 2000).

Under surface drip irrigation, soil evaporation is nonetheless inevitable. The solution to this was the introduction of subsurface drip irrigation which still came with its own disadvantages. Crop rotations became inherently inflexible since crop bed widths could not be varied (Burt and Barreras, 2001). Moving the drip lines closer to the surface has become a possible solution to problems associated with both surface and subsurface drip irrigation. The new system is called retrievable drip irrigation.

Wide soil water content fluctuations and soil temperature variations on the soil surface or near the soil surface are experienced not only under surface drip irrigation but also under other irrigation methods. Soil water content fluctuations and temperature variations under surface drip irrigation depend on soil type, environment and irrigation interval. Relative evapotranspiration decreases with decreasing soil water content as the soil water content in the profile is controlled by the atmospheric demand for evapotranspiration rate due to external environmental conditions (Singh and Singh, 2002). Wide soil temperature variation in the root zone results in poor root uptake of water at low temperature and also results in reduction of root uptake of nutrients at high temperature (Kuiper, 1964; House and Jarvis, 1968).

In an experiment in Canada, temperature on the soil surface increased from 26 to $42^{\circ} \mathrm{C}$ for surface drip lines (Parchomchuk, 1976) whereas on drip lines covered with $15 \mathrm{~cm}$ of soil, the maximum soil temperature on the soil surface reduced from 42 to $32^{\circ} \mathrm{C}$ (Parchomchuk, 1976). Drip lines covered by soil help to keep the soil surface dry thus reducing soil evaporation. The top $20 \mathrm{~cm}$ of soil had lower water content resulting in reduced soil evaporation when drip lines were buried at the depth of $45 \mathrm{~cm}$ (Phene et al., 1983). They also outlined the following problems as being associated with subsurface drip irrigation: inspection of a subsurface system is very difficult; emitters' clogging by roots and solids may cause poor system performance; and a subsurface system is difficult to be repaired and maintained.

Lamm and Trooien (2005) and Neelam and Rajput (2007) examined the effect of drip line depth on subsurface drip-irrigated field corn grown on deep silt loam soils of western Kansas. Results indicated that drip line depths ranging from 0.20 to $0.61 \mathrm{~m}$ are acceptable for field-corn production on silt loam soils in the region. They recommended that placement of drip lines might be practical at depths less than $10 \mathrm{~cm}$ under sandy loam soil.

Neelam and Rajput (2007) evaluated the effect of the depth of placement of drip lines on yield of potato at 0,5 , 10,15 and $20 \mathrm{~cm}$ under sandy loam soil. When drip lines were buried at the depth of $5 \mathrm{~cm}$, upward movement of water took place. When drip lines were buried at the depths of 20 to $61 \mathrm{~cm}$ under deep silt loam soil of western Kansas, soil temperature variation was greatly moderated (Lamm and Trooien, 2005).

The interactive effect of covering drip lines with dune sand on soil water content and soil temperature regimes should also have a profound effect on plant growth and, therefore, merits investigation. Dhavu et al. (2010) found out that Tottori dune sand has self-mulching properties. The effect on soil water content fluctuations and soil temperature variations by covering drip lines with the Tottori dune sand has however not been evaluated yet. The objectives of this study were to determine the minimum cover on drip lines with the Tottori dune sand and to study the effects of different levels of application of irrigation water on soil water content fluctuations and soil temperature variations. The dune sand cover effect on soil water content and soil temperature would be further related to sorghum crop growth (plant height and dry matter yield). "Covering drip lines with dune sand has no effect on soil water content and soil temperature variation" was our null hypothesis.

\section{MATERIALS AND METHODS}

\section{Experimental layout}

The experiment was carried out in a $154 \mathrm{~m}^{2}$ area glasshouse at the Arid Land Research Center, Tottori University, Japan $\left(35^{\circ} 32^{\prime} \mathrm{N}\right.$; $134^{\circ} 13^{\prime} \mathrm{E} ; 23 \mathrm{~m}$ above sea level). It was unheated and naturally ventilated with a single continuous roof vent. Lateral windows were kept open during daytime. The soil type of the Tottori dune sand was Arenosol (silicious sand, typic Udipsamment) with 96\% sand (Qui et al., 1999). The relationship between soil water pressure and volumetric water content of the dune sand is shown in Figure 1. The water content at field capacity and permanent wilting point of the dune sand were, respectively, 0.074 and $0.022 \mathrm{~cm}^{3} / \mathrm{cm}^{3}$ which corresponded to the matric potential of $-0.006 \mathrm{MPa}$ and $-1.5 \mathrm{MPa}$, respectively (Qui et al., 1999). Porosity and saturated soil hydraulic conductivity of the dune sand were $0.4 \mathrm{~m}^{3} / \mathrm{m}^{3}$ and $2.7 \times 10^{-4} \mathrm{~m} / \mathrm{s}$, respectively (Qui et al., 1999). Some of the physical properties of the dune sand are summarized in Table 1.

Two plots (Plots A and B) were used in this experiment as shown in Figure 2. Sorghum (Sorghum bicolor) was planted on each subplot on June 16, 2008 at $50 \mathrm{~cm}$ row and $30 \mathrm{~cm}$ in-row spacing making 267000 plants per hectare. Fertilizer was applied at the rate of $180 \mathrm{~kg} / \mathrm{ha} \mathrm{N}, 45 \mathrm{~kg} / \mathrm{ha} \mathrm{P}$ and $80 \mathrm{~kg} / \mathrm{ha} \mathrm{K}$ just before sowing. After sowing the sorghum, the drip lines were covered with sand dune soil as shown in Figure 3. The sorghum was harvested on October 24, 2008.

\section{Thickness of cover}

Each of the two plots was further divided into three sub-plots. Three drip lines were arranged on each sub-plot. The drip lines were spaced at $50 \mathrm{~cm}$. Emitters was spaced at $30 \mathrm{~cm}$ along the drip lines. This irrigation system was operated at a pressure head of 14 $\mathrm{m}$. Three drip lines were not covered with the sand dune soil on the 


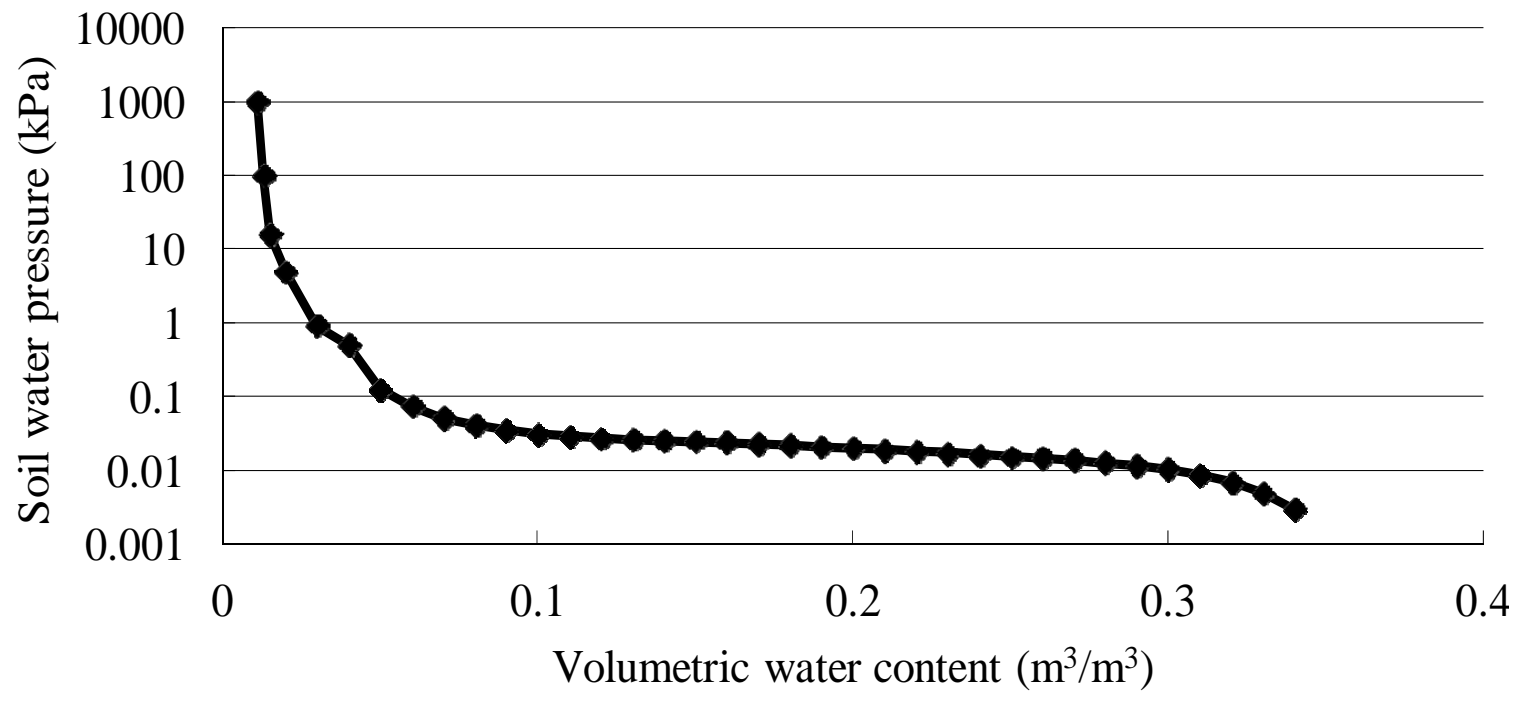

Figure 1. Soil water pressure and volumetric water content of the Tottori dune sand.

Table 1. Physical properties of Tottori dune sand.

\begin{tabular}{lcccc}
\hline \multirow{2}{*}{ Depth (cm) } & \multicolumn{3}{c}{ Particle size composition (\%) } & \multirow{2}{*}{ Bulk density $\left(\mathbf{M g} / \mathbf{m}^{\mathbf{3}}\right)$} \\
\cline { 2 - 4 } & Sand & Silt & Clay & 1.50 \\
\hline $0-5$ & 96.2 & 2.0 & 1.8 & 1.49 \\
$5-10$ & 95.7 & 3.0 & 1.3 & 1.49 \\
$10-15$ & 95.2 & 3.0 & 1.8 & 1.50 \\
$25-30$ & 94.7 & 3.5 & 1.8 & \\
\hline
\end{tabular}

control sub-plots of Plots A and B and this is referred to as TO. On two sub-plots of Plots $A$ and $B$, the drip lines were covered by 2 and $5 \mathrm{~cm}$ of the sand dune soil, and these are referred to as T2 and T5, respectively. The section view of the position of the drip lines, sensors and plants under T0, T2 and T5 is shown in Figure 3. Protrusion of drip lines was observed under T2 for both 0.6Ep and 1.0Ep during the growing period. This could have been caused by expansion and contraction of the drip lines due to temperature variations.

\section{Irrigation level}

Two small evaporation pans were placed in each sub-plot, and were weighed twice daily at 08:30 and at 20:30. Irrigation water was applied once in 2 days based on the small pan evaporation readings and scheduling.

Different irrigation levels were applied to Plots A and B. For Plot A, $100 \%$ of the estimated evapotranspiration of sorghum was applied and this is referred to as 1.0Ep. For Plot B, $60 \%$ of the estimated evapotranspiration of sorghum was applied and this is referred to as 0.6Ep.

\section{Evapotranspiration}

Evaporation from the small evaporation pan was converted to Class A pan evaporation using the Agodzo et al. (1997) equation:

$$
E_{A}=a \times E_{s}^{b}
$$

where, $E_{A}$ is Class $A$ pan evaporation ( $\mathrm{mm} / 2$ days), $a$ and $b$ are fitting parameters, with $a=0.17, b=1.92$ and $E_{S}$ is the evaporation from the small evaporation pan ( $\mathrm{mm} / 2$ days). Measured $E_{S}$ and $E_{A}$ were correlated for 10 days at the Arid Land Research Center, Tottori University, Japan.

Class A pan evaporation was then converted to the potential evapotranspiration using the Doorenbos and Pruit (1977) equation:

$\mathrm{ETo}=\mathrm{Kp} \times \mathrm{E}_{\mathrm{A}}$

where, ETo is the potential evaporation ( $\mathrm{mm} / 2$ days) and $\mathrm{Kp}$ is the pan coefficient (dimensionless). $\mathrm{Kp}=0.8$, and was obtained from $\mathrm{Kp}=0.75$ as given by Doorenbos and Pruit (1977) based on location, and adjusted by $7.5 \%$ to $\mathrm{Kp}=0.80$ for sorghum $(\mathrm{Kp}=$ $1.075 \times 0.75=0.80)$. The $\mathrm{Kp}$ values relate to evaporation pans located in an open field with no crops taller than one meter $(1 \mathrm{~m})$, and depend on general wind and humidity conditions of an area. The $\mathrm{Kp}$ values were therefore adjusted because the small evaporation pans were placed in a glasshouse (a small enclosure) and surrounded by sorghum.

The ETo from Equation (2) was converted to evapotranspiration of sorghum (ETc) ( $\mathrm{mm} / 2$ days) using the Doorenbos and Pruit (1977) equation:

$\mathrm{ETc}=\mathrm{Kc} \times \mathrm{ETo}$ 

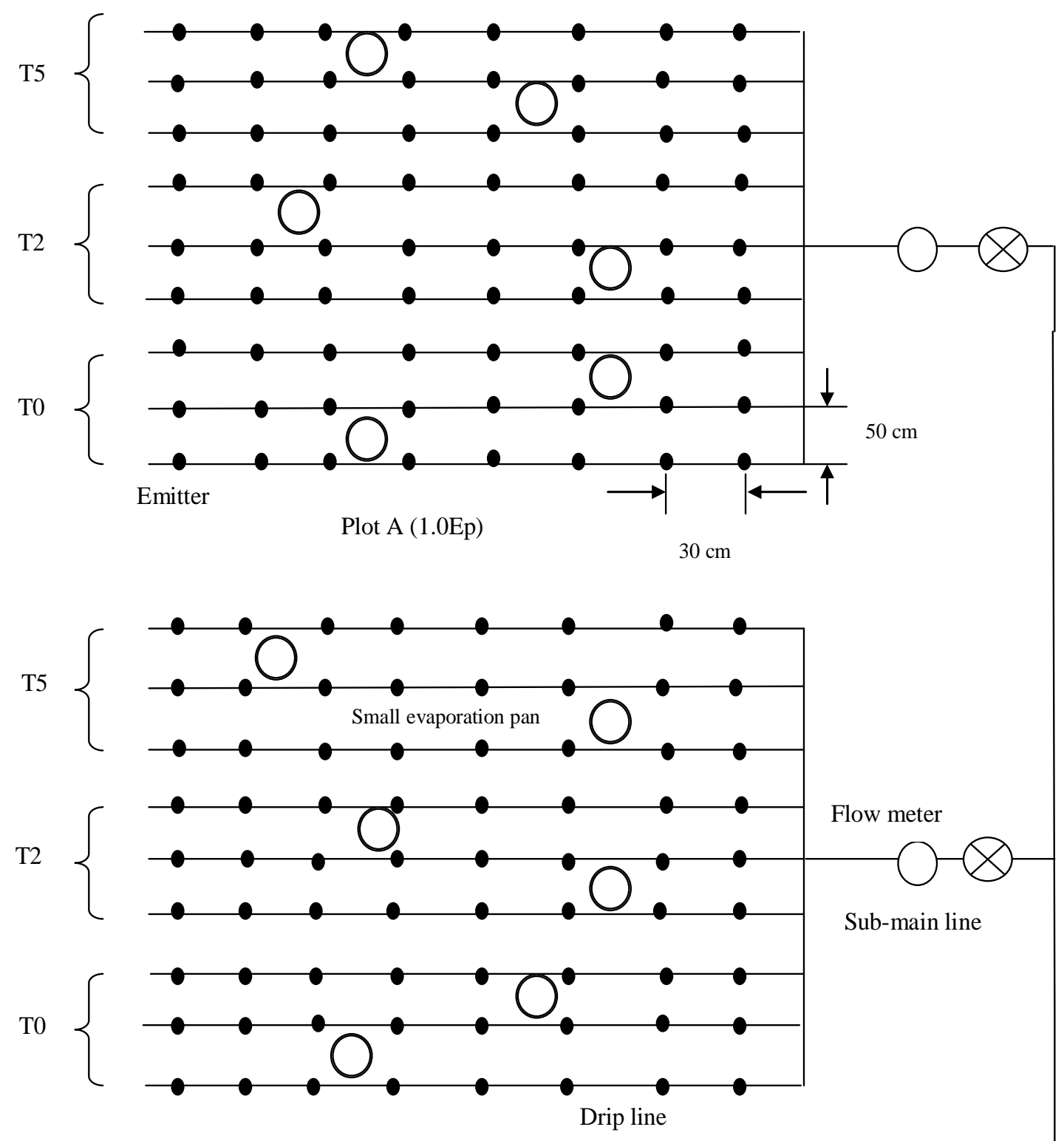

Main line

Plot B (0.6Ep)

Temperature and humidity sensor

Figure 2. Experiment plots.

where, $\mathrm{Kc}$ is the crop coefficient (dimensionless). The Allen et al. (1998) Kc values of 0.7, 1.1 and 0.55 for early growth stage, middle growth stage and late growth stage, respectively were used in this experiment.

Irrigation time was calculated from the following equations:

$$
\mathrm{T}=\frac{\mathrm{A} \times 0.6 \times \mathrm{ETC}}{\mathrm{Q}}
$$




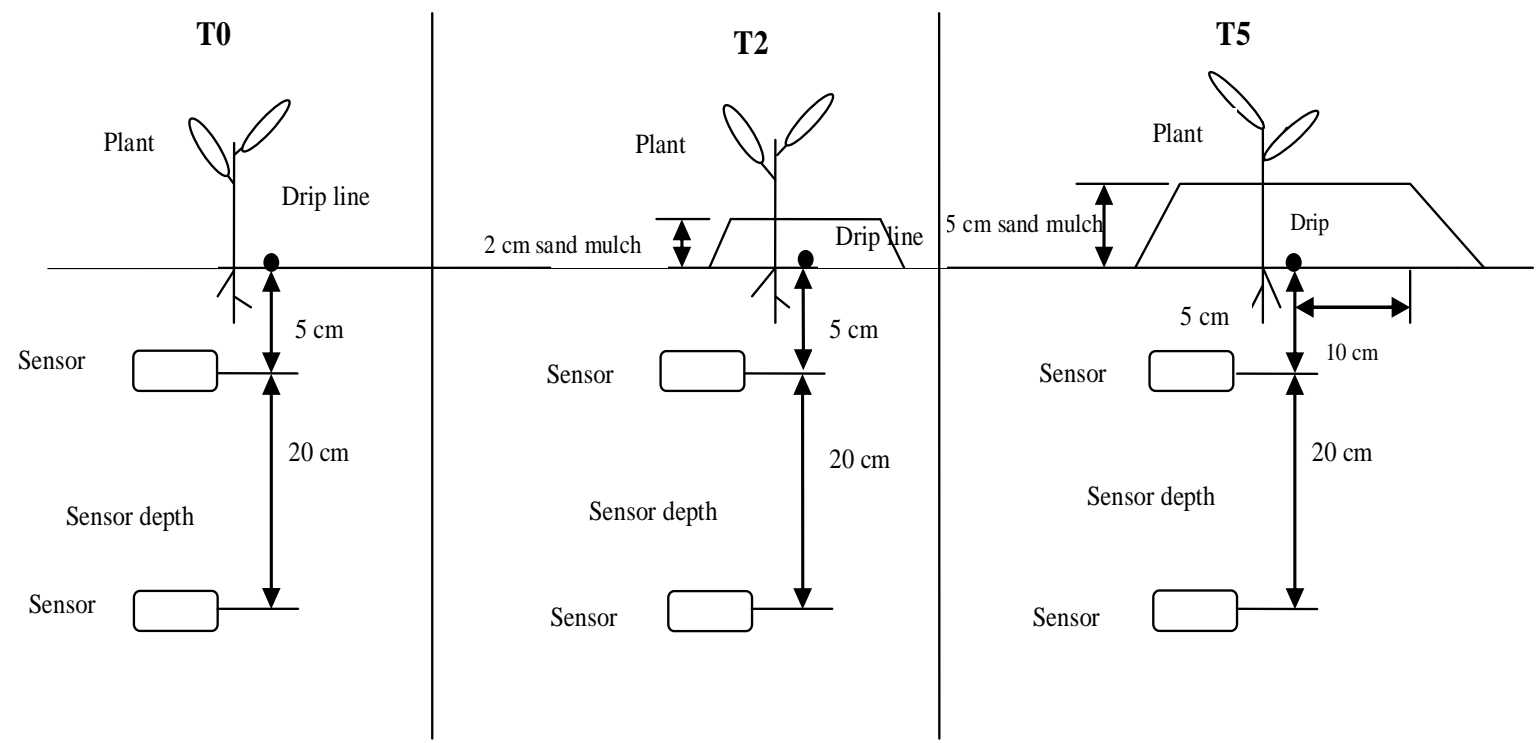

Figure 3. Section view of the position of drip lines and sensors under T0, T2 and T5.

Table 2. Climatic conditions in glasshouse.

\begin{tabular}{lccc}
\hline \multirow{2}{*}{ Month } & \multicolumn{2}{c}{ Air temperature $\left({ }^{\circ} \mathbf{C}\right)$} & \multirow{2}{*}{ Average humidity (\%) } \\
\cline { 2 - 3 } & Maximum & Minimum & 83 \\
June & 31.1 & 12.4 & 80 \\
July & 35.9 & 16.7 & 81 \\
August & 39.5 & 18.1 & 80 \\
September & 33.8 & 13.7 & 76 \\
October & 28.5 & 9.4 & \\
\hline
\end{tabular}

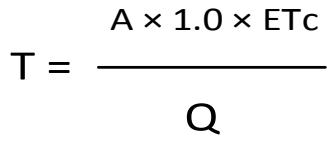

where, $\mathrm{T}$ is the irrigation time (hours), ETc as previously defined ( $\mathrm{mm} / 2$ days), $A$ is the wetted area (assumed circular and of measured radius of $15 \mathrm{~cm})\left(\mathrm{m}^{2}\right)$ and $\mathrm{Q}$ is the emitter discharge $(\mathrm{l} / \mathrm{h})$.

\section{Soil water content and soil temperature}

Soil water content was measured using $\mathrm{ECH}_{2} \mathrm{O}$ capacitance probes (Decagon Devices Inc., Pullman, Washington, USA) installed at depths of 5 and $25 \mathrm{~cm}$. The sensor installation depth of $25 \mathrm{~cm}$ was based on Yamamoto and Cho (1978) who reported that the most effective root-water uptake zone in the sand dune soil under surface drip irrigation was the top $25 \mathrm{~cm}$.

Water content was not measured at the surface because the sand dune soil dries quickly. Water content was recorded every hour by Em50 $\mathrm{ECH}_{2} \mathrm{O}$ data loggers (Decagon Devices Inc., Pullman, Washington, USA). Soil temperature was measured by thermocouples (copper-constantan thermocouples) installed at depths of 5 and $25 \mathrm{~cm}$. Soil temperature was measured every 15 min and averaged over one hour intervals by $21 \mathrm{X}$ and CR10X data loggers.

\section{Climate condition and plant growth}

Air temperature and humidity in the glasshouse were measured at a height of $2 \mathrm{~m}$ by ESPEC temperature and humidity sensors (ESPEC MIC Corp., Aichi, Japan). These were installed at the center of the glasshouse. Air temperature and humidity were recorded ever hour by ESPEC data loggers (ESPEC MIC Corp., Aichi, Japan). The climate conditions in the glasshouse are summarized in Table 2 . The maximum is the highest daily air temperature in each month and the minimum is the lowest daily air temperature in each month.

Three plants were randomly selected from each sub-plot of Plots $A$ and $B$ for measurement of plant height and dry matter weight. Plant height measured from dune sand surface to the latest leaf was measured at early stage, middle stage and late stage by a meter rule. At the late stage, plant height was also measured for each plant row to determine the plant height distribution. After harvesting, the dry matter weight was measured after drying the samples in an oven at $70^{\circ} \mathrm{C}$ for $48 \mathrm{~h}$.

\section{RESULTS AND DISCUSSION}

The total amount of irrigation water applied to each dune mulch treatment during the cropping period was $344 \mathrm{~mm}$ 


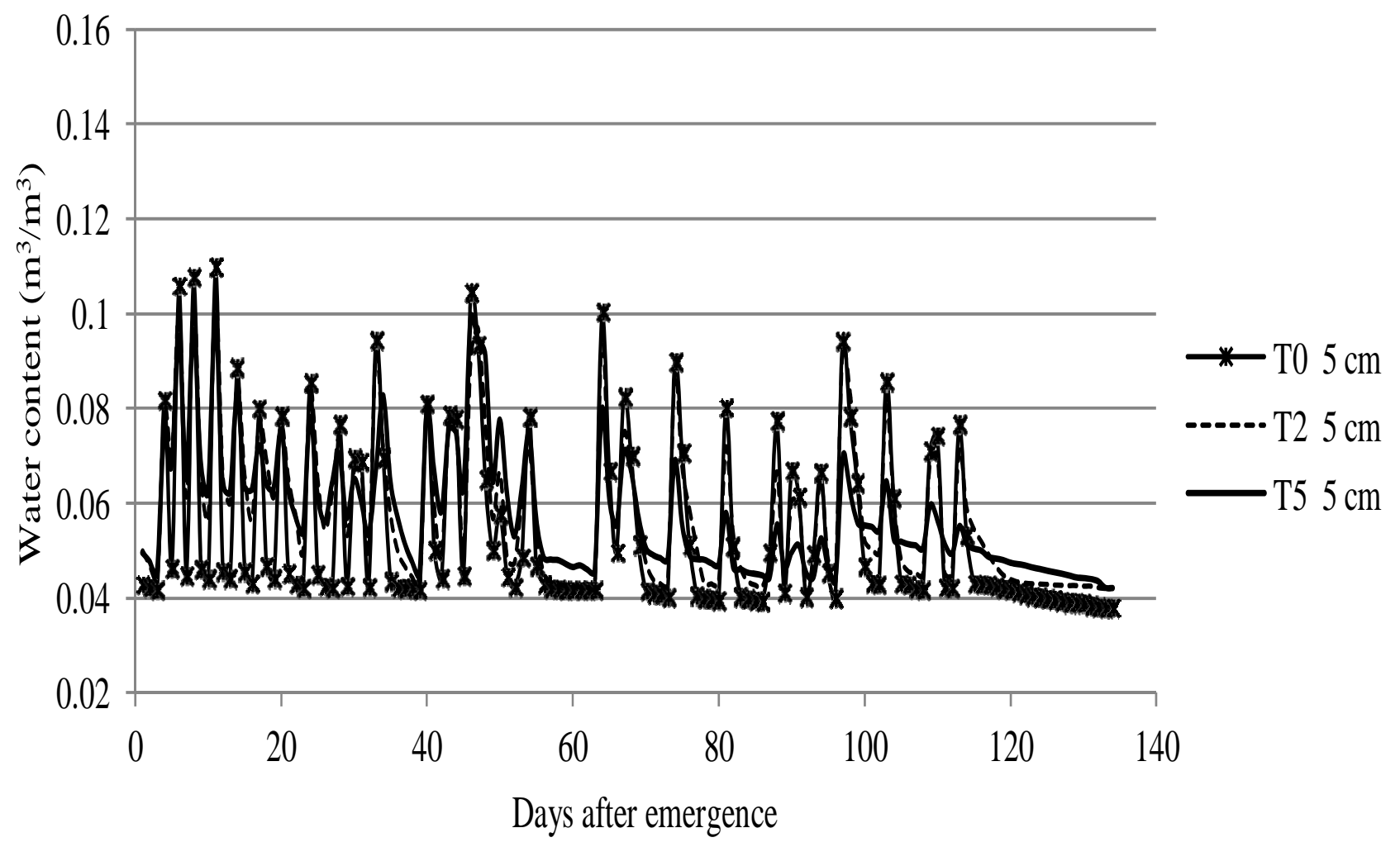

Figure 4. Soil water content at the depth of $5 \mathrm{~cm}(0.6 \mathrm{Ep})$.

for 0.6Ep and $521 \mathrm{~mm}$ for 1.0Ep.

\section{Variation of soil water content}

Variations of daily soil water content at the depth of $5 \mathrm{~cm}$ under T0, T2 and T5 for 0.6Ep are shown in Figure 4. The variations of daily water content at the depth of $5 \mathrm{~cm}$ are important since seed germination and emergence occur effectively up to this depth (Smith et al., 1999). Smith et al. (1999) found percentages of emergence close to $100 \%$ down to a depth of $5 \mathrm{~cm}$ with a drastic fall afterwards. Daily water content is the average of hourly water content per day.

Soil water content under TO reached highest peaks immediately after application of irrigation water as compared to the water content peaks reached under T2 and T5. Soil water content under T5 reached lowest peaks as compared to the water content peaks reached under T0 and T2. The observed trend could have been because water losses through soil evaporation and/or seepages from the $5 \mathrm{~cm}$ depth were fastest under T0. This is evidenced by the sharp drop in soil water content under T0. Soil water content during the growing season of sorghum had a range of $0.072 \mathrm{~m}^{3} / \mathrm{m}^{3}, 0.062 \mathrm{~m}^{3} / \mathrm{m}^{3}$ and $0.057 \mathrm{~m}^{3} / \mathrm{m}^{3}$ under T0, T2 and T5, respectively as shown in Table 3. This means soil water content under T0 experienced the widest fluctuations, while experiencing the narrowest fluctuations under T5. The average soil water content under T0, T2 and T5 at the depth of $5 \mathrm{~cm}$ were however not significantly different at $P<0.001$.

Variations of soil water content at the depth of $25 \mathrm{~cm}$ under T0, T2 and T5 for 0.6Ep are shown in Figure 5 and summarized in Table 3 . The variations of soil water content at the depth of $25 \mathrm{~cm}$ are important for plant root growth and nutrient uptake as reported by Yamamoto and Cho (1978). Similar trends as observed at the depth of $5 \mathrm{~cm}$ in soil water content variation under T0, T2 and $\mathrm{T} 5$ at the depth of $25 \mathrm{~cm}$ were observed. The maximum soil water content reached were, however not as high as experienced at the depth of $5 \mathrm{~cm}$. Consistent with infiltration theory (Smith et al., 1969), soil water contents reached maximum directly under the drip lines while the minimum soil water content was lowest under T0. Covering the drip lines with 2 and $5 \mathrm{~cm}$ sand dune soil reduced the maximum daily soil water content and raised the minimum daily soil water content at the depth of 25 $\mathrm{cm}$ probably through soil evaporation reduction. The average soil water content under T0, T2 and T5 at the depth of $25 \mathrm{~cm}$ was significantly different from those under T0, T2 and T5 at depth of $5 \mathrm{~cm}$ for 0.6Ep ( $\mathrm{P}<$ 0.001 ). Variations of soil water content at the depth of 5 $\mathrm{cm}$ under T0, T2 and T5 for 1.0Ep are shown in Figure 6. The high peaks around 75 to 80 days after emergence 
Table 3. Soil water content peaks and averages for the growth period.

\begin{tabular}{|c|c|c|c|c|c|c|c|}
\hline $\begin{array}{c}\text { Irrigation } \\
\text { level }\end{array}$ & $\begin{array}{l}\text { Depth } \\
\text { (cm) }\end{array}$ & $\begin{array}{l}\text { Sand } \\
\text { cover }\end{array}$ & $\begin{array}{c}\text { Maximum } \\
\left(\mathrm{m}^{3} / \mathrm{m}^{3}\right)\end{array}$ & $\begin{array}{c}\text { Minimum } \\
\left(\mathrm{m}^{3} / \mathrm{m}^{3}\right) \\
\end{array}$ & $\begin{array}{c}\text { Range } \\
\left(\mathrm{m}^{3} / \mathrm{m}^{3}\right)\end{array}$ & $\begin{array}{l}\text { Average } \\
\left(\mathrm{m}^{3} / \mathrm{m}^{3}\right)\end{array}$ & $\begin{array}{c}\text { SD } \\
\left(\mathrm{m}^{3} / \mathrm{m}^{3}\right)\end{array}$ \\
\hline \multirow{6}{*}{ 0.6Ep } & \multirow{3}{*}{5} & T0 & 0.110 & 0.038 & 0.072 & $0.054^{\mathrm{a}}$ & 0.019 \\
\hline & & T2 & 0.104 & 0.041 & 0.062 & $0.058^{\mathrm{a}}$ & 0.015 \\
\hline & & T5 & 0.099 & 0.042 & 0.057 & $0.058^{\mathrm{a}}$ & 0.013 \\
\hline & \multirow{3}{*}{25} & TO & 0.105 & 0.049 & 0.056 & $0.064^{b}$ & 0.014 \\
\hline & & T2 & 0.107 & 0.057 & 0.050 & $0.072^{c}$ & 0.013 \\
\hline & & T5 & 0.095 & 0.065 & 0.030 & $0.075^{c}$ & 0.005 \\
\hline \multirow{6}{*}{ 1.0Ep } & \multirow{3}{*}{5} & T0 & 0.157 & 0.032 & 0.125 & $0.061^{b}$ & 0.026 \\
\hline & & T2 & 0.101 & 0.035 & 0.065 & $0.065^{d}$ & 0.017 \\
\hline & & T5 & 0.093 & 0.048 & 0.044 & $0.068^{c d}$ & 0.012 \\
\hline & \multirow{3}{*}{25} & TO & 0.120 & 0.044 & 0.073 & $0.069^{c d}$ & 0.018 \\
\hline & & T2 & 0.102 & 0.055 & 0.047 & $0.072^{c}$ & 0.009 \\
\hline & & T5 & 0.102 & 0.057 & 0.045 & $0.074^{c}$ & 0.009 \\
\hline
\end{tabular}

Values followed by different letters are significantly different at $\mathrm{P}<0.001, \mathrm{SD}$ is standard deviation.

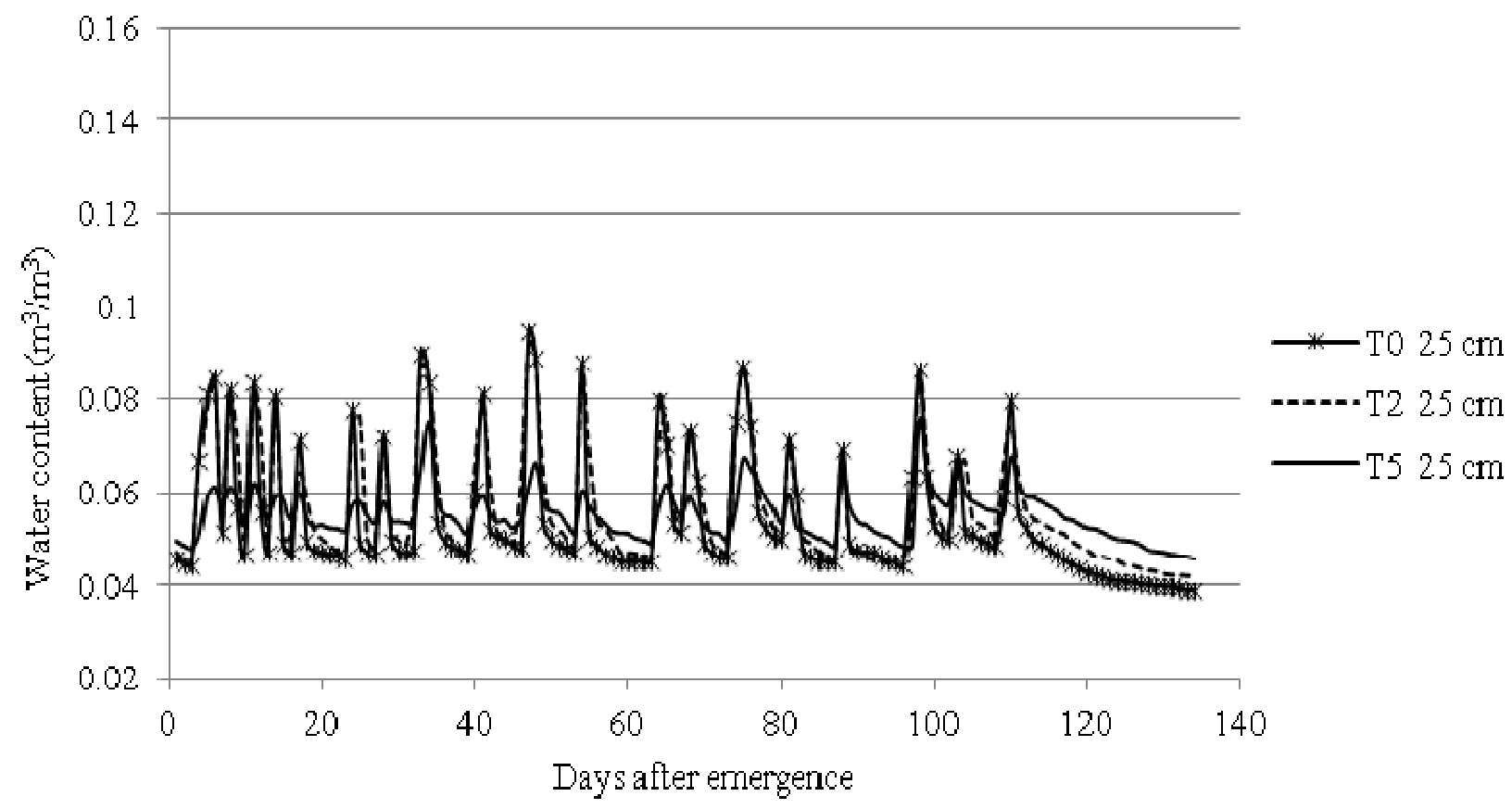

Figure 5. Soil water content at the depth of $25 \mathrm{~cm}(0.6 \mathrm{Ep})$

could have been because of high temperatures experienced in August. The soil water content variations under T0, T2 and T5 for 1.0Ep also follow the same trend as observed for $0.6 \mathrm{Ep}$. The average soil water content under TO at the depth of $5 \mathrm{~cm}$ for 1.0Ep was however significantly different from those under T2 and T5 $(P<$ 0.001).
The variations as shown by the ranges in Table 3 are wider for 1.0Ep than for 0.6Ep at the same depth of $5 \mathrm{~cm}$ under the three different dune sand covers except for T5. The variations for 1.0Ep are wider probably due to more irrigation water applied as compared to those for 0.6Ep which applied only $60 \%$ of the water lost through evapotranspiration. Deficit irrigation together with dune 


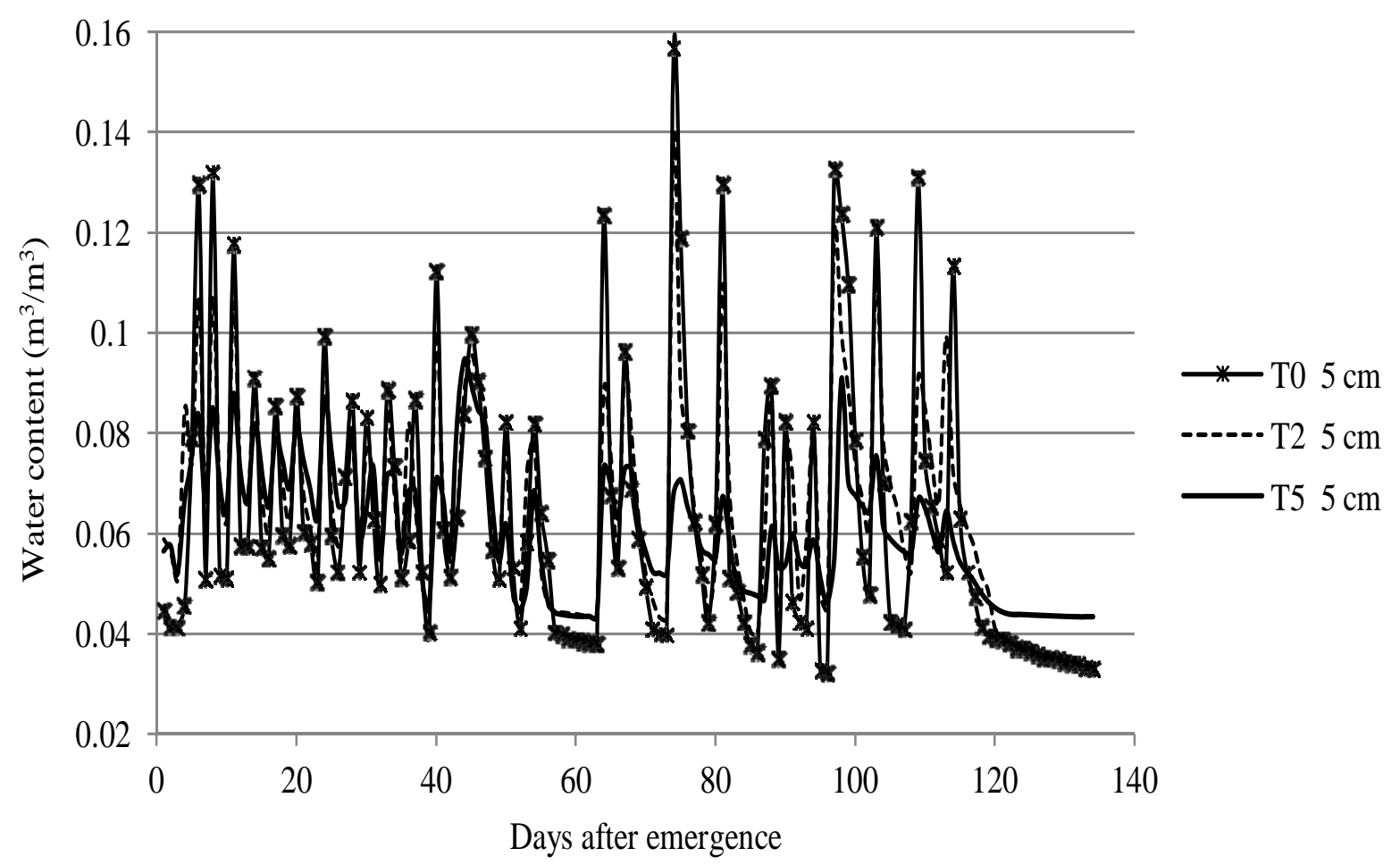

Figure 6. Soil water content at the depth of $5 \mathrm{~cm}$ (1.0Ep).

sand cover of 2 and $5 \mathrm{~cm}$ help reduce soil water content variation under retrievable drip irrigation. Dry dune sand cover helps to reduce soil water content loss through soil evaporation. Deficit irrigation on the other hand, reduces the peak soil water content that could be reached when full irrigation is practiced. The trend in these results is similar to those found by Gunduz et al. (2011). They found that the fluctuations of soil water content was greater in treatments that received more water than in those that received less water. Variations of soil water content at the depth of $25 \mathrm{~cm}$ under T0, T2 and T5 for 1.0Ep are shown in Figure 7. The soil water content variations under T0, T2 and T5 also follow the same trend as observed at the depth of $5 \mathrm{~cm}$ and at the same depth of $25 \mathrm{~cm}$ but for $0.6 \mathrm{Ep}$. The variations are however narrower at the depth of $25 \mathrm{~cm}$ than those at the depth of $5 \mathrm{~cm}$ while they are generally wider for 1.0Ep than 0.6Ep at the same depth of $25 \mathrm{~cm}$ under the three different dune sand covers. There were probably less soil evaporation and deep percolation losses from the depth of $25 \mathrm{~cm}$ than that from the depth of $5 \mathrm{~cm}$. The effect of water vapor adsorption is lower at the depth of $25 \mathrm{~cm}$ than at the depth of $5 \mathrm{~cm}$, hence lower soil water content peaks at the depth of $25 \mathrm{~cm}$. These results are consistent with those found by Kosmas et al. (1998) who found that diurnal fluctuations of soil water content decreased with increasing soil depth, soil wetness and surface mulching due to water vapor adsorption. Soil water content variations are summarized in Table 3. Generally, there is higher soil water content under dune sand mulch than under unmulched dune sand. Ramakrishma et al. (2006) also observed higher soil water content in the 0 to $60 \mathrm{~cm}$ soil layer of the mulched plots compared to that of the unmulched plots. They also observed higher soil evaporation from unmulched plots than from the mulched plots. From Table 3, the variations of soil water content at the depths of 5 and $25 \mathrm{~cm}$ were wider under T0, T2 and T5 for 1.0Ep than under T0, T2 and T5 for 0.6Ep. Narrower variations of daily water content for $0.6 \mathrm{Ep}$ than for 1.0Ep were because insufficient irrigation water was applied for 0.6Ep. Therefore, the combination of T5 and $0.6 \mathrm{Ep}$ was the best in reducing the variations of daily water content. This response was important since the most effective root-water uptake zone in the Tottori dune sand is up to the depth of $25 \mathrm{~cm}$ (Yamamoto and Cho, 1978).

\section{Variation of soil temperature}

Variations of daily soil temperature at the depths of $5 \mathrm{~cm}$ under T0, T2 and T5 for 0.6Ep are shown in Figure 8. The variations of daily soil temperature at the depth of 5 $\mathrm{cm}$ are important since seed germination and emergence occur effectively up to this depth (Smith et al., 1999).

Daily soil temperature was the average of hourly soil 


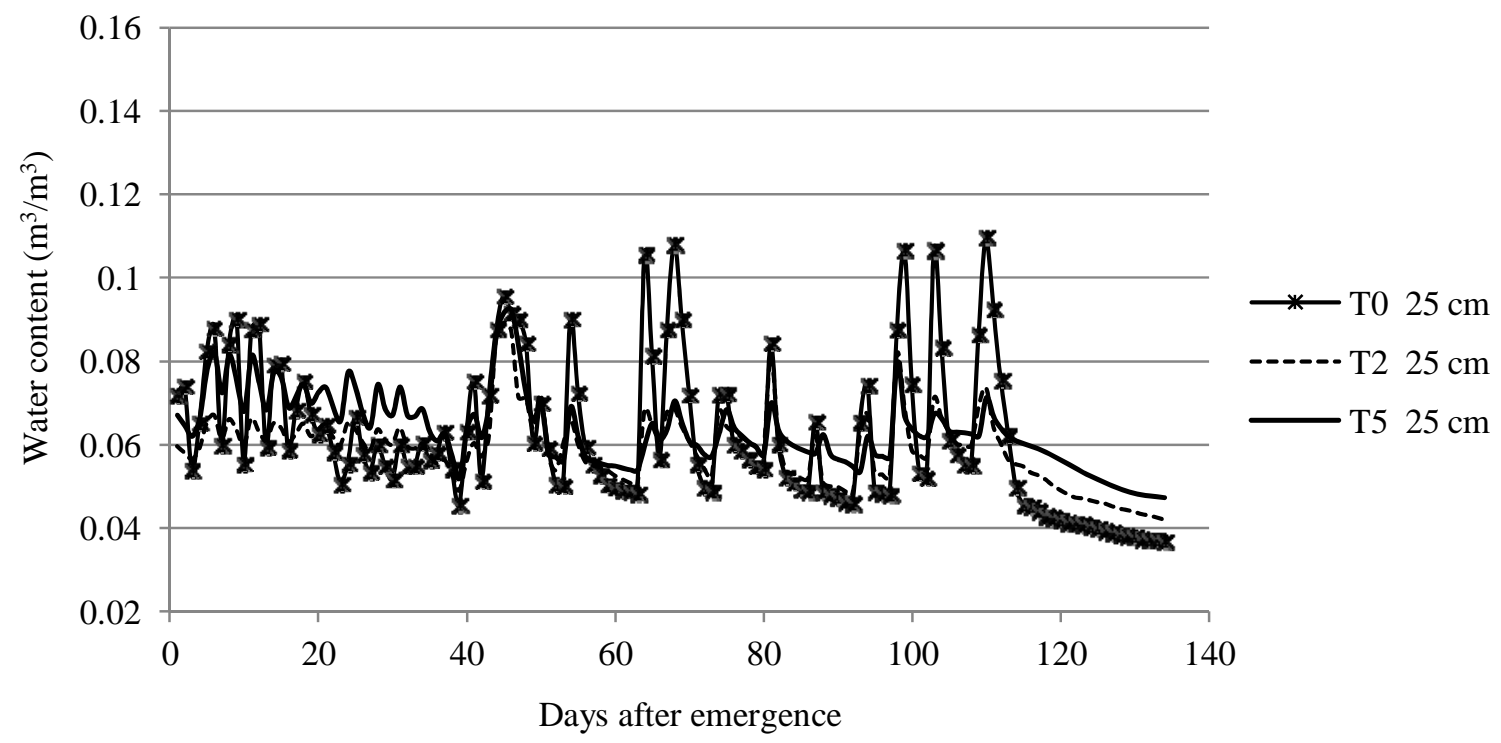

Figure 7. Soil water content at the depth of $25 \mathrm{~cm}$ (1.0Ep).

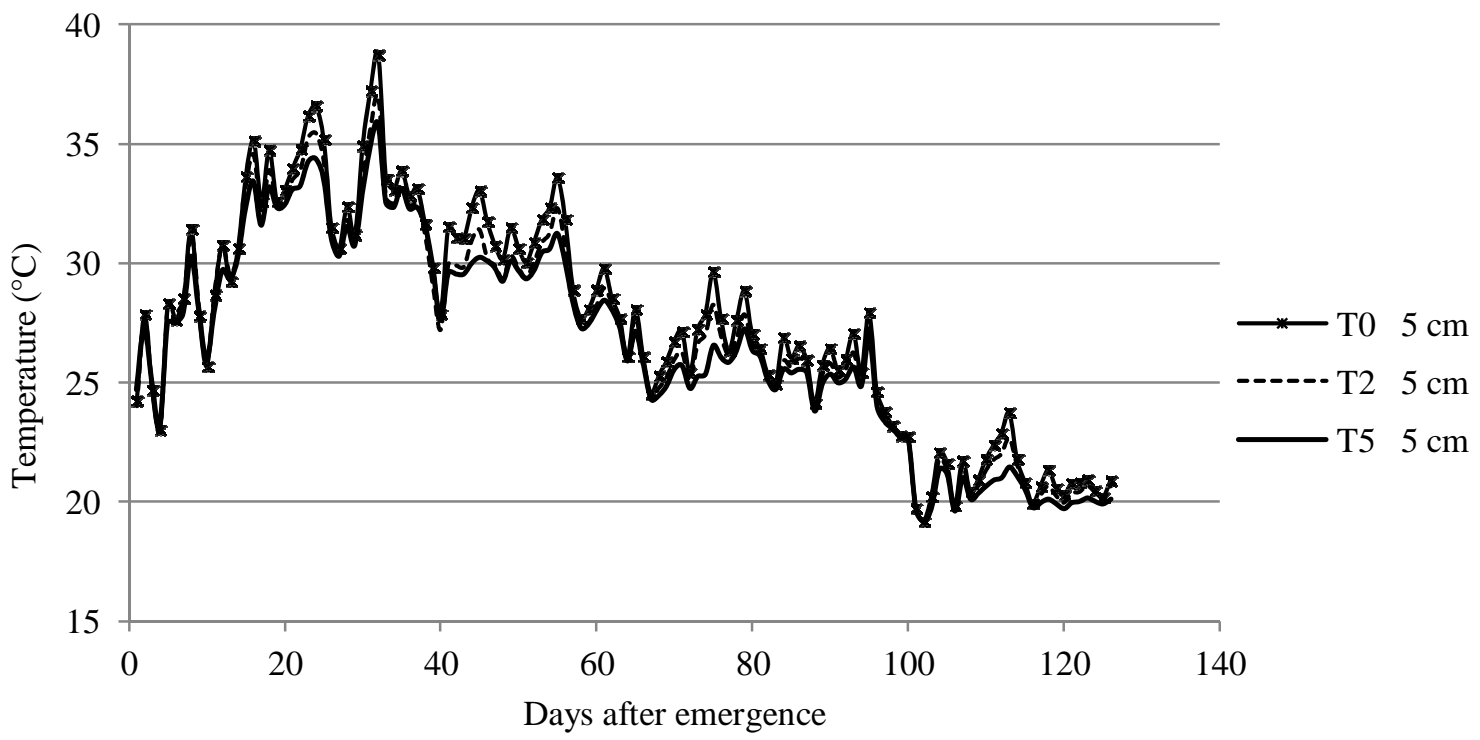

Figure 8. Daily soil temperature at the depth of $5 \mathrm{~cm}(0.6 \mathrm{Ep})$.

temperature recorded per day. Daily soil temperature at the depth of $5 \mathrm{~cm}$ under T0 was significantly different $(P<$ 0.001) from those of both T2 and T5 during the growing period with highest soil temperatures being reached under T0 and the lowest being reached under T5. Covering the drip lines by 2 and $5 \mathrm{~cm}$ dune sand reduced the soil temperature at the depth of $5 \mathrm{~cm}$. These results are in agreement with findings by Varadan and Rao (1983) who found that soil temperature differences under mulched and unmulched conditions were significant within the first $10 \mathrm{~cm}$ of soil depth.
Variations of daily soil temperature at the depth of 25 $\mathrm{cm}$ under T0, T2 and T5 for 0.6Ep are shown in Figure 9. Similar trends in soil temperature variations were observed at the depth of $25 \mathrm{~cm}$ as those at the depth of 5 $\mathrm{cm}$. Highest soil temperatures as also shown in Table 4 were observed under T0 while the lowest soil temperatures were observed under T5. Soil temperatures under T0, T2 and T5 at the depth of $25 \mathrm{~cm}$ were significantly different $(P<0.001)$ from each other and from those at the depth of $5 \mathrm{~cm}$. Covering the drip lines by $5 \mathrm{~cm}$ sand soil narrowed the variations of daily soil 
Table 4. Soil temperature peaks and averages for the growth period.

\begin{tabular}{|c|c|c|c|c|c|c|c|}
\hline $\begin{array}{c}\text { Irrigation } \\
\text { level }\end{array}$ & $\begin{array}{l}\text { Depth } \\
\text { (cm) }\end{array}$ & $\begin{array}{l}\text { Sand } \\
\text { cover }\end{array}$ & $\begin{array}{c}\text { Maximum } \\
\left({ }^{\circ} \mathrm{C}\right)\end{array}$ & $\begin{array}{c}\text { Minimum } \\
\left({ }^{\circ} \mathrm{C}\right)\end{array}$ & $\begin{array}{c}\text { Range } \\
\left({ }^{\circ} \mathrm{C}\right)\end{array}$ & $\begin{array}{c}\text { Average } \\
\left({ }^{\circ} \mathrm{C}\right)\end{array}$ & $\begin{array}{l}\text { SD } \\
\left({ }^{\circ} \mathrm{C}\right)\end{array}$ \\
\hline \multirow{7}{*}{ 0.6Ep } & \multirow{4}{*}{5} & TO & 38.75 & 19.20 & 19.55 & $27.59^{\mathrm{a}}$ & 4.672 \\
\hline & & T2 & 36.95 & 19.15 & 17.80 & $27.06^{\mathrm{b}}$ & 4.445 \\
\hline & & T5 & 35.85 & 19.15 & 16.70 & $26.68^{b}$ & 4.370 \\
\hline & & & & & & & \\
\hline & \multirow{3}{*}{25} & то & 36.40 & 18.95 & 17.45 & $26.15^{c}$ & 4.131 \\
\hline & & T2 & 31.55 & 18.75 & 12.80 & $24.54^{d}$ & 3.352 \\
\hline & & T5 & 30.13 & 17.65 & 12.48 & $23.64^{\mathrm{e}}$ & 3.184 \\
\hline \multirow{7}{*}{ 1.0Ep } & \multirow{4}{*}{5} & T0 & 38.20 & 18.75 & 19.45 & $27.12^{\mathrm{ab}}$ & 4.751 \\
\hline & & T2 & 35.10 & 18.00 & 17.10 & $26.20^{\mathrm{ce}}$ & 4.533 \\
\hline & & T5 & 34.00 & 17.75 & 16.25 & $25.52^{f}$ & 4.532 \\
\hline & & & & & & & \\
\hline & \multirow{3}{*}{25} & Tо & 34.85 & 17.50 & 17.35 & $24.96^{d}$ & 4.218 \\
\hline & & T2 & 31.70 & 17.45 & 14.25 & $23.84^{\mathrm{e}}$ & 3.683 \\
\hline & & T5 & 29.90 & 17.35 & 12.55 & $23.01^{g}$ & 3.552 \\
\hline
\end{tabular}

Values followed by different letters are significantly different at $P<0.001, S D$ is standard deviation.

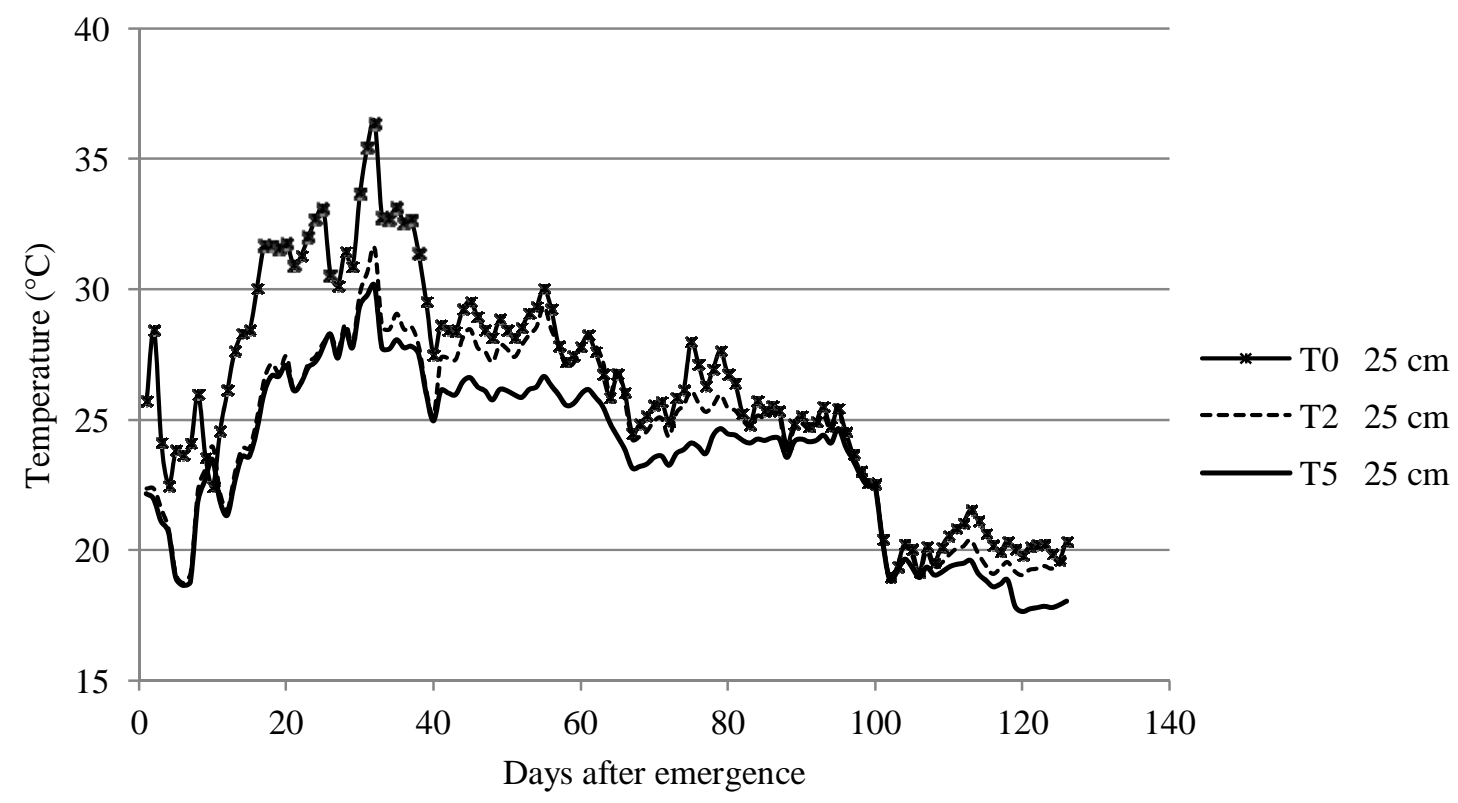

Figure 9. Daily soil temperature at the depth of $25 \mathrm{~cm}(0.6 \mathrm{Ep})$.

temperature.

Variations of daily soil temperature at the depths of $5 \mathrm{~cm}$ under T0, T2 and T5 for 1.0Ep are shown in Figure 10 and summarized in Table 4. Again, we observed highest temperatures under T0 while the lowest temperatures were observed under T5. From this figure and table, it can be seen that covering the drip lines by 2 and $5 \mathrm{~cm}$ of sand dune soil results in significantly different $(P<0.001)$ soil temperature.

Variations of daily soil temperature at the depths of 25 $\mathrm{cm}$ under T0, T2 and T5 for 1.0Ep are shown in Figure 11. Again, we observed highest soil temperatures under T0 while the lowest temperatures were observed under T5. From this figure, it can also be seen that covering the 


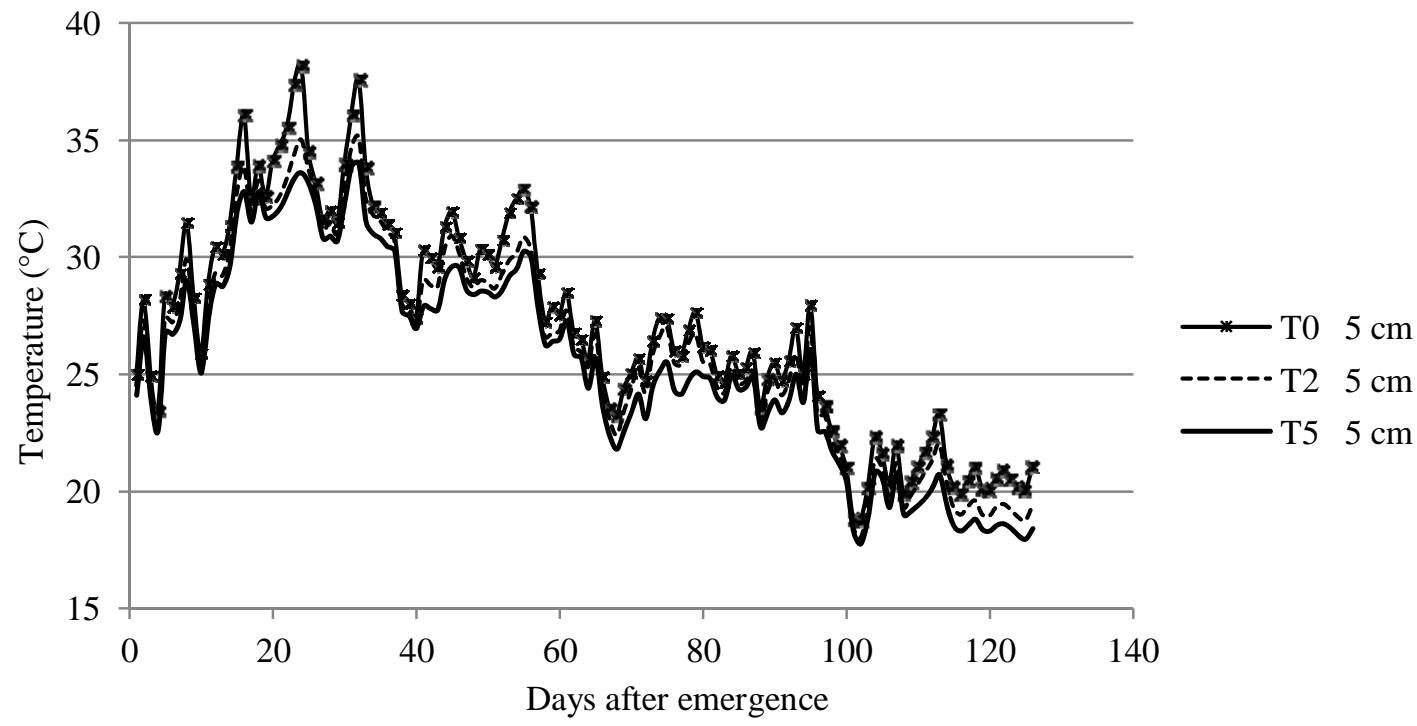

Figure 10. Daily soil temperature at the depth of $5 \mathrm{~cm}(1.0 \mathrm{Ep})$.

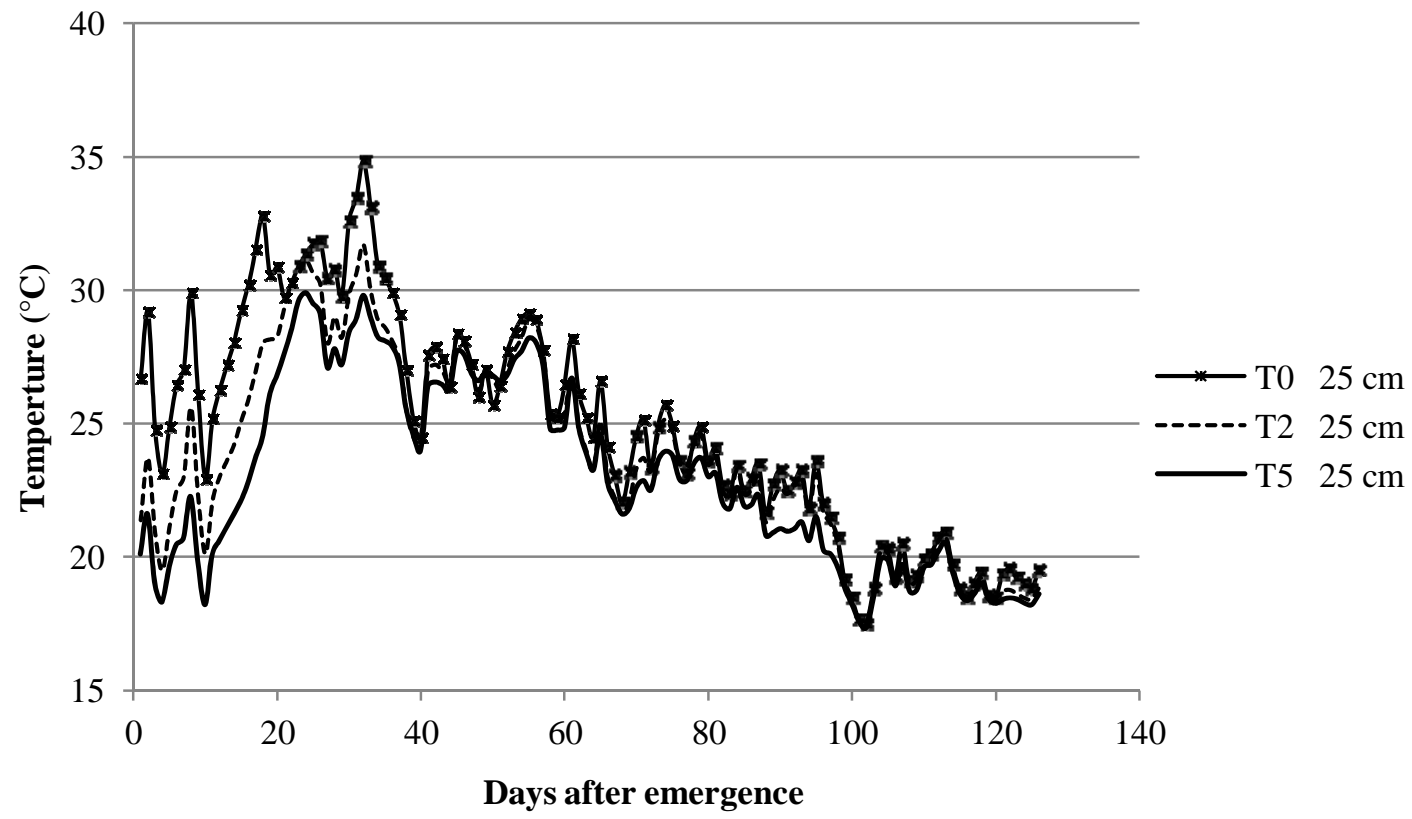

Figure 11. Daily soil temperature at the depth of $25 \mathrm{~cm}$ (1.0Ep).

drip lines by 2 and $5 \mathrm{~cm}$ of sand dune soil lowers soil temperature. Chiemeka (2010) also found out that soil temperature was highest at the depth of $5 \mathrm{~cm}$. The $5 \mathrm{~cm}$ depth is closer to the earth's surface and the solar radiation reaches that depth before other layers (Chiemeka, 2010).

Soil temperature variations are summarized in Table 4. The maximum soil temperature is the highest soil temperature during the growing season. The minimum soil temperature is the lowest soil temperature during the growing season. Soil temperature variation is the difference between maximum and minimum soil temperatures observed during the growing season.

The average daily soil temperatures at the depths of 5 and $25 \mathrm{~cm}$ were higher under T0, T2 and T5 for 0.6Ep than under T0, T2 and T5 for 1.0Ep. Covering the drip lines by $5 \mathrm{~cm}$ and applying sufficient irrigation water resulted in the reduction of the daily soil temperature more than that of covering the drip lines by $5 \mathrm{~cm}$ and applying insufficient irrigation water. 


\section{Crop growth}

Plant heights at three growth stages under T0, T2 and T5 for $0.6 \mathrm{Ep}$ and 1.0Ep are shown in Figure 12. For 0.6Ep, the plant heights at the three growth stages under T0, T2 and T5 were not significantly different at $P<0.001$. These results show that covering the drip lines by 2 and 5 $\mathrm{cm}$ dune sand under deficit irrigation had no significant effect on the vegetative growth of sorghum. This could have been because insufficient irrigation water was applied.

For $1.0 \mathrm{Ep}$, the plant heights at the early growth stage under T0, T2 and T5 were not significantly different at P < 0.001. At the middle growth stage, the plant heights under T0, T2 and T5 were significantly different at P < 0.001 . At the late growth stage, the plant heights under T5 were significantly different from those under TO and T2. Covering the drip lines by $5 \mathrm{~cm}$ sand dune soil significantly supported the vegetative growth of sorghum. This result could be because the $5 \mathrm{~cm}$ dune sand mulch help to maintain stable soil temperatures and soil water content.

At the early growth stage, the plant heights under T0, T2 and T5 were not significantly different $(P<0.001)$ for both $0.6 \mathrm{Ep}$ and 1.0Ep. During the early growth stage, the bulk of evapotranspiration could be through soil evaporation and at this stage the 0.6Ep and 1.0Ep were still almost equally exposed to factors of soil evaporation. At the late stage, the plant heights under T5 for 1.0Ep were significantly higher than T5 for $0.6 \mathrm{Ep}$. Soil temperature variations caused expansion and contraction of drip lines under T2 for 0.6Ep and 1.0Ep. The expansion and contraction of the drip lines caused some sections of the drip lines to protrude to the soil surface. This caused poor growth distribution along the drip lines. Covering the drip lines by $5 \mathrm{~cm}$ dune sand and applying sufficient irrigation water supported the vegetative growth of sorghum. These results are consistent with findings by other researchers. Sammis et al. (1988) reported that plant height can change at different levels of deficit irrigation. Some researchers stressed that deficit irrigation shortened plant height (Stone et al. 2001; Pandey et al. 2000).

Dry matter yields under T0, T2 and T5 for 0.6Ep and 1.0Ep are shown in Table 5. For 0.6Ep, the dry matter yield under T5 was higher than that under T0 and T2. The average plant weight under T0 and T2 was significantly different $(P<0.001)$ from that under T5. Low dry matter yields of sorghum have been reported by other researchers (Oliver et al., 2005; Marsalis et al., 2010). Previous research has shown that yield levels are environment and variety specific (Casler et al., 2003). The increase in plant weight and yield with dune sand cover could be attributed to higher soil water content retained in the soil due to the dune sand mulch. Surya et al. (2000) concluded that the greater soil water content under mulch as important implications on the utilization of water by crop and soil reactions that control the availability of nutrients and biological nitrogen fixation. For 1.0Ep, the dry matter yield under T5 was higher than those of T0 and T2. Covering the drip lines by $5 \mathrm{~cm}$ significantly increased the dry matter yield of sorghum. The dry matter yield under T5 was higher than the recommended dry matter yield of sorghum.

There was insignificant increase in the dry matter yields under T2 for 0.6Ep and 1.0Ep. The dry matter yield was higher under T5 for 1.0Ep than under T5 for 0.6Ep. The dry matter yields under T0, T2 and T5 for 1.0Ep were higher than for 0.6Ep. This was because sufficient irrigation water was applied for 1.0Ep as compared to that for 0.6Ep thus improving soil water availability. Improved soil water availability can result in taller and more robust plants, a larger average leaf area increased vegetative dry matter and promote leaf tip emergence, flowering and grain filling (Abrecht and Carberry, 1993).

The dry matter yield of sorghum was highest under T5 for both $0.6 \mathrm{Ep}$ and 1.0Ep. This phenomenon could be attributed to the improvement in soil water content and soil temperature conditions relative to those under TO. The sand dune soil cover prevents evaporation of water from the soil surface. At the same time, water moves from deeper soil layers to the topsoil by capillarity and vapor transfer, thereby keeping the topsoil (ideally $25 \mathrm{~cm}$ for Tottori sand dune soil under drip irrigation) water content relatively stable (Wang et al., 1998; Li et al., 1999). This result is consistent with the results obtained by Li et al. $(1999,2004)$ for maize growth.

Covering the drip lines by $5 \mathrm{~cm}$ sand dune soil and applying sufficient irrigation water was the best combination that reduced the variations of daily water content and daily soil temperature. This combination resulted in the increase in the dry matter yield of sorghum of about $20 \%$. Sand dune soil cover can significantly affect the soil microclimate (soil temperature and soil water content) (Ghosh et al., 2006), and hence plant growth components. Yi et al. (2011) also found that mulches improve topsoil water retention and decreased soil temperature when compared to non-mulched surfaces.

\section{Conclusions}

Observations from this glasshouse study indicate that soil water content and soil temperature variations in the soil, under retrievable drip irrigation can be different depending on the drip irrigation management system. Soil water content and soil temperature variations were reduced by 2 and $5 \mathrm{~cm}$ dune sand cover.

Covering the drip lines by $2 \mathrm{~cm}$ dune sand, however, had the problems of expansion and contraction of the drip lines. The drip lines protruded out of the soil because of this problem. The $2 \mathrm{~cm}$ dune sand cover is therefore not a practical cover for drip lines to reduce the variations of 

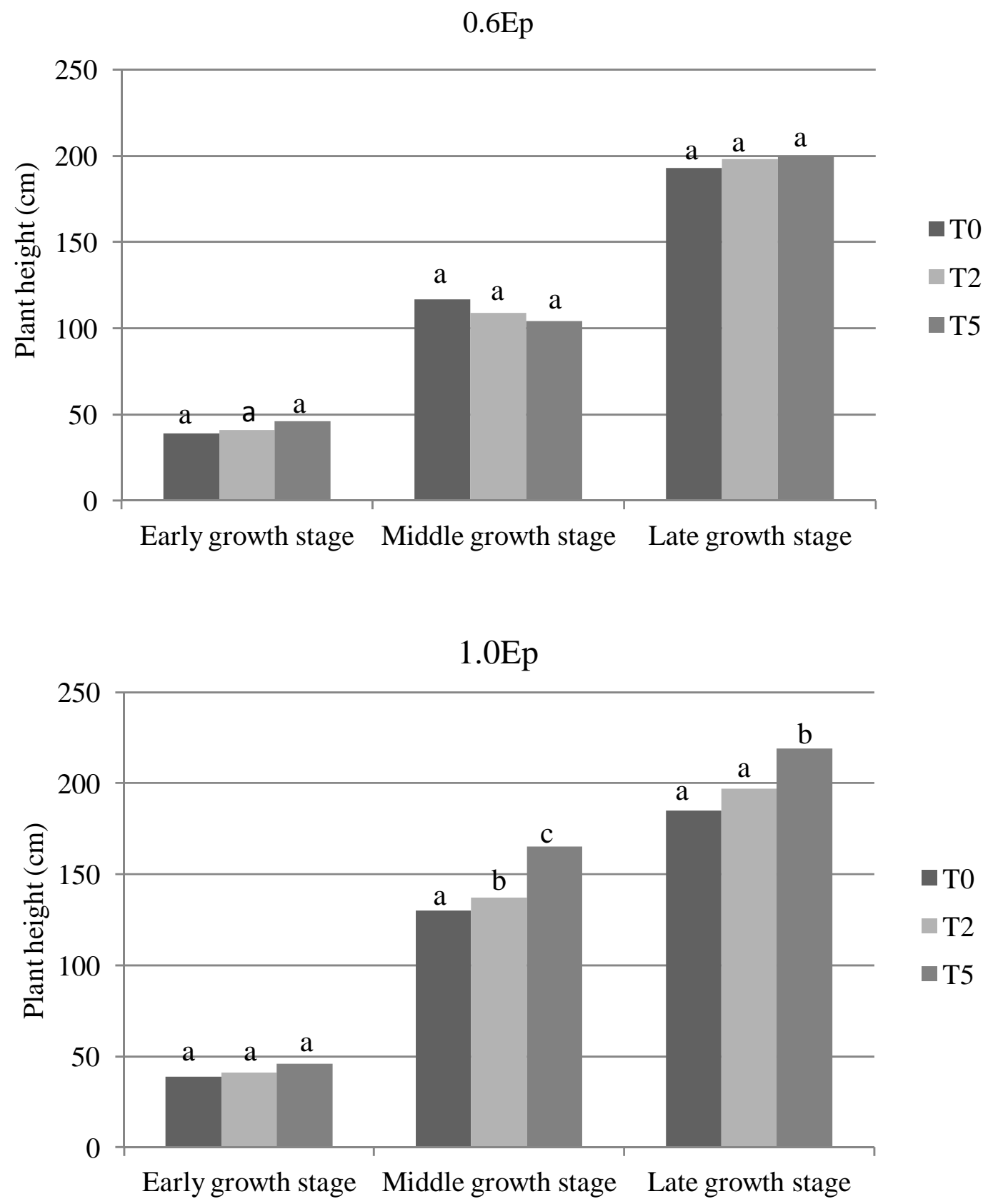

Figure 12. Plant height at three growth stages for 0.6Ep and 1.0Ep (Bars within the same growth stage for both $0.6 \mathrm{Ep}$ and $1.0 \mathrm{Ep}$ with different letters on top are significantly different at $\mathrm{P}<0.001$ ).

Table 5. Dry matter yield under T0, T2 and T5 for 0.6Ep and 1.0Ep.

\begin{tabular}{|c|c|c|c|c|c|c|}
\hline \multirow[b]{2}{*}{ Sand cover } & \multicolumn{3}{|c|}{$0.6 \mathrm{Ep}$} & \multicolumn{3}{|c|}{ 1.0Ep } \\
\hline & $\begin{array}{c}\text { Yield } \\
\left(\mathrm{kg} / \mathrm{m}^{2}\right)\end{array}$ & $\begin{array}{c}\text { Mean } \\
(\mathrm{kg})\end{array}$ & $\begin{array}{l}\text { SD } \\
(\mathrm{kg})\end{array}$ & $\begin{array}{c}\text { Yield } \\
\left(\mathrm{kg} / \mathrm{m}^{2}\right)\end{array}$ & $\begin{array}{c}\text { Mean } \\
(\mathrm{kg})\end{array}$ & $\begin{array}{r}\text { SD } \\
(\mathrm{kg})\end{array}$ \\
\hline TO & 1.8 & $0.19 a$ & 0.02 & 2.5 & $0.19 a$ & 0.08 \\
\hline T2 & 1.9 & $0.22 \mathrm{a}$ & 0.03 & 2.2 & $0.24 b$ & 0.07 \\
\hline T5 & 2.1 & $0.32 \mathrm{~b}$ & 0.07 & 3.0 & $0.34 \mathrm{c}$ & 0.06 \\
\hline
\end{tabular}

Values followed by different letters within a column are significantly different at $\mathrm{P}<0.001$, SD is standard deviation. 
daily water content and daily soil temperature. Maximum soil temperature was reduced by covering the drip lines by $5 \mathrm{~cm}$ sand soil. The variations of daily water content and daily soil temperature were best reduced under $5 \mathrm{~cm}$ sand soil cover and sufficient irrigation water. The combinations of $5 \mathrm{~cm}$ sand dune soil cover and sufficient irrigation resulted in increased sorghum plant height and sorghum dry matter yield.

\section{Conflict of Interests}

The authors have not declared any conflict of interests.

\section{REFERENCES}

Agodzo SK, Nishio T, Yamamoto T (1997). Trickle irrigation of okra based on small pan evaporation schedule under glasshouse condition. Rural Environ. Eng. J. 33:19-36.

Abrecht DG, Carberry PS (1993). The influence of water deficit prior to tassel initiation on maize growth, development and yield. Field Crops Res. 31:55-69 http://dx.doi.org/10.1016/0378-4290(93)90050-W

Allen RG, Pereira LS, Raes D, Smith M (1998). Crop evapotranspiration. FAO Irrigation and Drainage Paper 56, Food and Agriculture Organization of the United Nations, Rome, Italy, pp. 5256.

Burt CM, Barreras JT (2001). Retrievable drip irrigation systems: an alternative to SDI. Irrigat. J. May/June: pp. 17-20

Camp CR (1998). Subsurface drip irrigation: a review. Transactions of the Am. Soc. Agric. Eng. 45(5):1353-1367. http://dx.doi.org/10.13031/2013.17309

Casler MD, Pedersen JF, Undersander DJ (2003). Forage yield and economic losses associated with brown-midrib trait in sudangrass. Crop Sci. 43:782-789http://dx.doi.org/10.2135/cropsci2003.7820 http://dx.doi.org/10.2135/cropsci2003.0782

Chiemeka IU (2010). Soil temperature profile at Uturu, Nigeria. The Pacific J. Sci. Technol. 11(1):478-482.

Dhavu K, Anyoji H, Yasuda H (2010). Possibility of self-mulching material Tottori sand dune soil to reduce soil evaporation. Sand Dune Res. 57(1):1-10.

Doorenbos J, Pruit WO (1977). Crop water requirements. FAO Irrigation and Drainage Paper 24. Food and Agriculture Organization of the United Nations, Rome, Italy pp. 30-34.

Ghosh PK, Dayal D, Bandyopadhyay KK, Mohanty M (2006). Evaluation of straw and polythene mulch for enhancing productivity of irrigated summer groundnut. Field Crops Res. 99:76-86 http://dx.doi.org/10.1016/j.fcr.2006.03.004

Gunduz M, Korkmaz N, Asik S, Unal HB, Avci M (2011). Effects of various irrigation regimes on soil water balance, yield and fruit quality of drip-irrigated peach trees. J. Irrig. Drain. Eng. 137(7):426-434 http://dx.doi.org/10.1061/(ASCE)IR.1943-4774.0000310

House CR, Jarvis $P$ (1968). Effect of temperature on the radial change of labeled water in maize roots. J. Experi. Bot. 19:31-40. http://dx.doi.org/10.1093/jxb/19.1.31

Kosmas C, Danalatos NG, Poesen J, van Wesemael B (1998). The effect of water vapor adsorption on soil moisture content under Mediterranean climatic conditions, Agric. Water Manage 36:157-168 http://dx.doi.org/10.1016/S0378-3774(97)00050-4

Kuiper PJC (1964). Water uptake of higher plants as affected by root temperature. Mededelingen Landbouw Hogeschool, Wageningen, 64:1-11.

Lamm FR, Trooien TP (2005). Dripline depth effects on corn production when crop establishment is non-limiting. Transactions of the Am. Soc. Agric. Eng. 21(5):835-840.

Li FM, Guo AH, Wei H (1999). Effects of plastic film mulch on yield of spring wheat. Field Crops Res 63:79-86 http://dx.doi.org/10.1016/S0378-4290(99)00027-1
Li FM, Wang P, Wang J, Xu JZ (2004). Effects of irrigation before sowing and plastic film mulching on yield and water uptake of spring wheat in semiarid Loess Plateau of China. Agric. Water Manage. 67:77-88http://dx.doi.org/10.1016/j.agwat.2004.02.001

Long FD, Spears TD (2003). Water scarcity and 11/9/201.1 Valmont Industries, Inc., Valley, Nebraska, pp 65-72. PMid:12755352

Marsalis MA, Angadi SV, Contreras-Govea FE (2010). Dry matter yield and nutritive value of corn, forage sorghum, and BMR forage sorghum at different plant populations and nitrogen rates. Field Crops Res. 116(1-2):52-57http://dx.doi.org/10.1016/j.fcr.2009.11.009.

Neelam P, Rajput TBS (2007). Effect of drip tape placement depth and irrigation level on yield of potato. Agric. Water Manage. 32(3):209223.

Oliver AL, Pedersen JF, Grant RJ, Klopfenstein TJ (2005). Comparative effects of the sorghum mbr-6 and bmr-12 genes I. Forage sorghum yield and quality. Crop Sci. 45:2234-2239. http://dx.doi.org/10.2135/cropsci2004.0644 http://dx.doi.org/10.2135/cropsci2004.0660

Pandey RK, Maranville JW, Chetima MM (2000). Deficit irrigation and nitrogen effects on maize in a Sahelian environment II. Shoot growth,

nitrogen uptake and water extraction. Agric. Water Manage. 46(1):15-27 http://dx.doi.org/10.1016/S0378-3774(00)00073-1 http://dx.doi.org/10.1016/S0378-3774(00)00074-3

Parchomchuk P (1976). Temperature effects on emitter discharge rates. Transactions of the Am. Soc. Agric. Eng. 19(4):690-692. http://dx.doi.org/10.13031/2013.36097

Phene CJ, Blume MF, Hile MMS, Meek DW, Re JV (1983). Management of subsurface trickle irrigation systems, Transact. Am. Soc. Agric. Eng. pp. 2583-2598.

Qui GY, Ben-Asher J, Yano T, Momii K (1999). Estimation of evaporation using differential temperature method. Soil Sci. Soc. Am. J. 63:1608-1614http://dx.doi.org/10.2136/sssaj1999.6361608x

Ramakrishma A, Tam HM, Wani SP, Long TD (2006). Effect of mulch on soil temperature, moisture, weed infestation and yield of groundnut in northern Vietnam. Field Crops Res. 95:115-125. http://dx.doi.org/10.1016/j.fcr.2005.01.030

Sammis TW, Smeal D, Williams S (1988). Predicting corn yield under limited irrigation using plant height. Transactions of the ASAE 3(13):830 - 838. http://dx.doi.org/10.13031/2013.30788

Shiklomanov I (1998). Pictures of the future: a review of global water resources projections. The world's water 2000-2001, Island Press, Washington DC, pp. 40-59.

Smith GL, Freckleton RP, Firbank LG, Watkinson AR (1999). The population dynamics of Anisantha Sterilis in winter wheat: comparative demography and the role of management. J. Appl. Ecol. 36:455 - 471. http://dx.doi.org/10.1046/j.1365-2664.1999.00420.x

Smith RE, Smetten KRJ, Broadbridge P, Woolhiser DA (1969). Infiltration Theory for Hydrologic Applications. American Geophysical Union Washington DC, pp. 31-34.

Stone PJ, Wilson DR, Reid JB, Gillespie RN (2001). Water deficit effects on sweet corn I. Water use, radiation use efficiency, growth, and yield. Aus. J. Agric. Res. 52:103-113 http://dx.doi.org/10.1071/AR99146 http://dx.doi.org/10.1071/AR99145

Surya JN, Puranik JB, Zadode SD, Deshmukh SD (2000). Effect of wheat straw incorporation on yield of green gram and wheat, soil fertility and microbiota. J. Maharashtra Agric. Univer. 25:158-160

Varadan KM, Rao AS (1983). Effect of mulch on soil temperature in humid tropical latosols under coconut (Cocos nucitera Linn) and banana (Musa paradisiaca). Agric. Meteorol. 28(4):375-386 http://dx.doi.org/10.1016/0002-1571(83)90013-4

Wang D, Shannon MC, Grieve CM, Yates SR (2000). Soil water and temperature regimes in drip and sprinkler irrigation, and implications to soybean emergence. Agricultural Water Managem 43:15-28. http://dx.doi.org/10.1016/S0378-3774(99)00057-8

Wang XQ, Li SX, Guo YT (1998). Effects of film mulch on physiecology and yield of spring corn. Acta Agronomica Sinica 24(3):348353

Yamamoto T, Cho T (1978). Soil moisture content distribution in main root-zone and water application efficiency of crop-studies on trickle irrigation method in sand field. Transactions of the Japanese Soc. Irrig. Drain. Reclam. Eng. 75:33-40.

Yi L, Yufang S, Shenjiao Y, Shiqing L, Fang C (2011). Effect of mulch 
and irrigation practices on soil water, soil temperature and grain yield of maize (Zea mays L) in Loess Plateau, China. Afr. J. Agric. Res. 6(10):2175-2182. 